\title{
Personnel
}

RUTHERFord D. Rogers assumes the position of University Librarian at Yale University July 1, 1969. For five years Stanford University

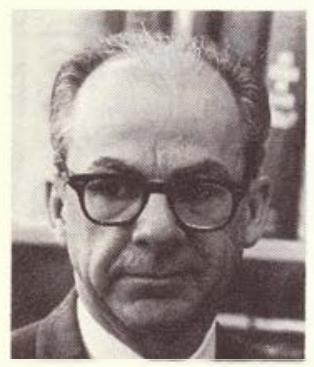

Mr. Rogers has been graced by one of the most able librarians in the field - a man whom Edward G. Freehafer described as combining "excellence with intelligence, success with modesty. As an administra tor, he guides with a gentle rein and under his direction things seem to fall naturally into their proper places." This is an accurate assessment, and no higher compliment can be bestowed. Rudy deserves all of the many accolades that he has received in his brilliant career.

In characterizing his career and his personality one seeks for such words as "gentleman," "scholar," "humanist"; yet these fall short of measuring the man. He is a combination of warm colleague, kind friend, and library administrator par excellence. With a keen mind, sharpness of perception, clarity in the spoken word, and lucid precision in writing, he has a singular ability to cut to the essence of a problem and a notable knack of keeping basic priorities of effort from being dissipated in useful but peripheral efforts. The result is that a library organization moves forward in strides. His years at Stanford enabled the institution to establish sharply increased levels of library performance, rate of growth, quality of staff, and, aided by the grace of his personality, to obtain for the library the enthusiastic backing by the University administration of a new level of library endeavor. Yale is to be congratulated on its choice.

Rudy was President of the Association of Research Libraries in 1967-68, and a member of its Board of Directors for the past three years. He has been Second Vice-President of the American Library Association in 1965-66; Chairman of the ARL Liaison Committee with the National Advisory Commission on Libraries in 1966-67; a member of the ALA Executive Board 196I-65; a Trustee of the ALA Endowment Fund 1966-68; Chairman of the Joint Libraries Committee on Fair Use in Photocopying, 1964-66; and a member of the USOE Advisory Committee for Title II of Library Services and Construction Act for California since 1965. He has been active in the Bibliographical
Society of America, the Archons of Colophon, the Grolier Club, the Cosmos Club, the Roxburghe Club of San Francisco, and the Book Club of California, as well as being a founding member of the United States Capitol Historical Society. He may have played a sparkling game of tennis in Washington, but he is also known on the West Coast as a formidable golf partner and a fanatical basketball fan.

California's loss is clearly Connecticut's gain, and his many close friends at Stanford University will miss Rudy and Margaret and their daughter, Janie, who have for five years been such a gracious part of the University and the Bay Area.-David C. Weber, Stanford University.

APPOINTMENTS

HANS BART has been named head, catalog department, University of Arizona library.

MARY W. Bootu has been appointed reference librarian, social sciences, at the University of Arizona.

Cynthia Butler has been appointed assistant librarian in the college of medicine library at the University of California, Irvine.

VIRgINIA CASSADX is acting instructional materials librarian, University of Arizona.

Richard $R$. Centing is now administrative assistant to the director at The Ohio State University libraries.

Charles Cutter has accepted the position of bibliographer and cataloger of Hebrew materials at the Ohio State University libraries.

Mrs. Kathryn Demange is the new acquisitions librarian in the University of Maryland health sciences library.

Mrs. Anya Derrick is now head of the bibliographical control division of the acquisitions department, Pennsylvania State University library.

Wayne Derrick has been appointed continuing education librarian with the commonwealth campus libraries, Pennsylvania State University.

Mrs. Peggy Dolsen has been appointed reference librarian, Washington University library.

Melayn Dorflek has returned to the serials department in the health sciences library, University of Maryland, where she is in charge of government documents.

Carole Noel Engel has been appointed head serials librarian at the medical center library, University of Virginia.

W. Peyton Fawcett has been named head librarian of the Field Museum of Natural History, Chicago, Illinois.

Ashby J. Fristoe has been appointed asso- 
ciate university librarian for technical services at the University of Hawaii library, effective July 1, 1969.

RuTH HaNna has returned to the staff of the health sciences library, University of Maryland, as a reference librarian.

RutH R. HEyum has joined the staff of the University of Hawaii library to develop the $\mathrm{Pa}$ cific Islands collection.

Mrs. Parvathi Hosain is now a cataloger in the University of Maryland health sciences library.

Mrs. Kenneth Irwin has been appointed to the position of serials-documents librarian at Beloit College, Beloit, Wisc., effective May 1 , 1969.

Mrs. Shirley Jones is now chief of the serials department, Washington University library.

Saldy ANN KeYes is now assistant librarian in charge of public services at Beloit College, Beloit, Wisc.

Mrs. Yoon-Whan Crror KIM is a new staff member in the Korean section of the Far Eastern library, University of Washington.

M. Carol Kish has been appointed reference-circulation librarian at Monroe County Community College, Monroe, Michigan.

William H. Kurth is now university li-
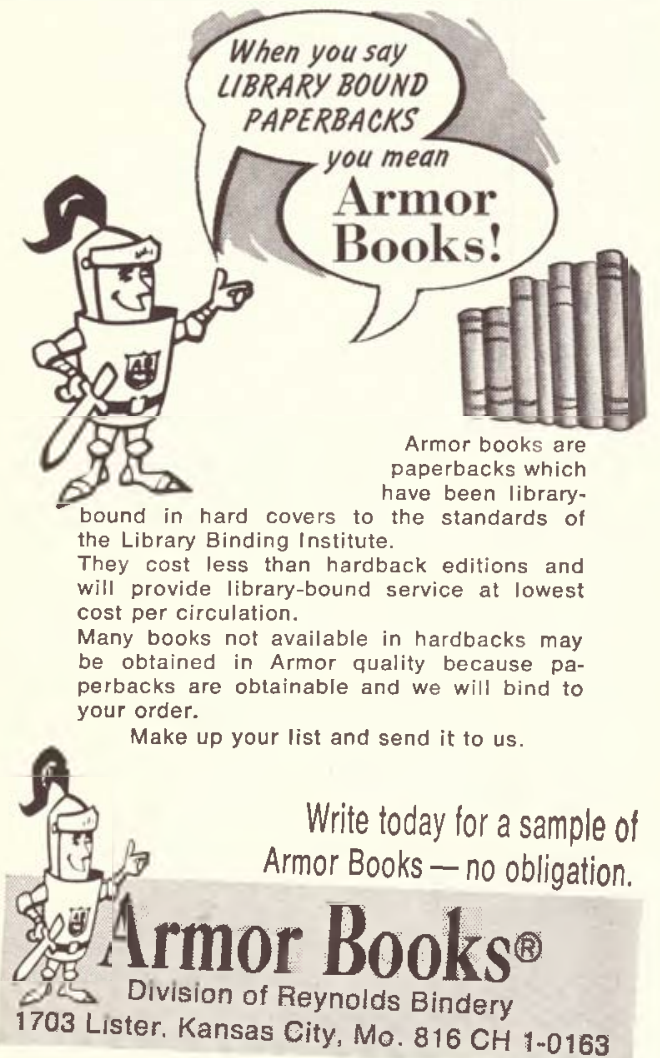

brarian and associate director of libraries, Washington University.

Mrs. MARY ListFELDT has been named acting head of the reference department, University of Maryland health sciences library.

MARy McWhorter has been appointed catalog librarian and lecturer in Oriental studies, University of Arizona.

Brita Miller is now a catalog librarian at the University of Arizona.

KenNeth Nabors has been appointed chief of the reference department, Washington University library.

Victor Novak has been named university librarian at the University of Santa Clara, Santa Clara, California.

Mrs. Donna E. Packer has joined the staff of the catalog division, University of Washington libraries.

Mrs. Patricia Riberro is now a cataloger in the University of Maryland health sciences library.

VIRginia Rice has been named senior reference librarian, University of Arizona.

Mrs. Carol Vogel Scrivens has been appointed librarian of the regional special education instructional materials center at Hunter College, City University of New York.

Mrs. Virginia Secrest is now head of the cataloging division, Washington University library.

Erinore E. Smrre has been appointed head, serials department, University of Arizona.

Norman D. Stevens has been named university associate librarian at the University of Connecticut.

Mrs. Enna Suber has been appointed to the new position of serials librarian in the Smithsonian Institution.

Thomas P. Williams has been appointed assistant professor and head, humanities and social science reference department at Mississippi State University.

Mrs. Teresa S. YANG has joined the staff of the Hoover Institution as a senior librarian.

\section{NECROLOG Y}

Mrs. Frederick S. Howell, head librarian of the Field Museum of Natural History, Chicago, Illinois, died on August 31, 1968.

Edwin W. Reichard, college librarian of California State College at Dominguez Hills, Gardena, California, died in December, 1968.

Mrs. Elleine H. Stones, former chief of the Burton Historical Collection of the Detroit Public library, died in Albuquerque, N.M. on January $5,1969$.

\section{RETIREMENTS}

Mrs. Lois BENNETT KNox has retired as circulation librarian after more than forty years 


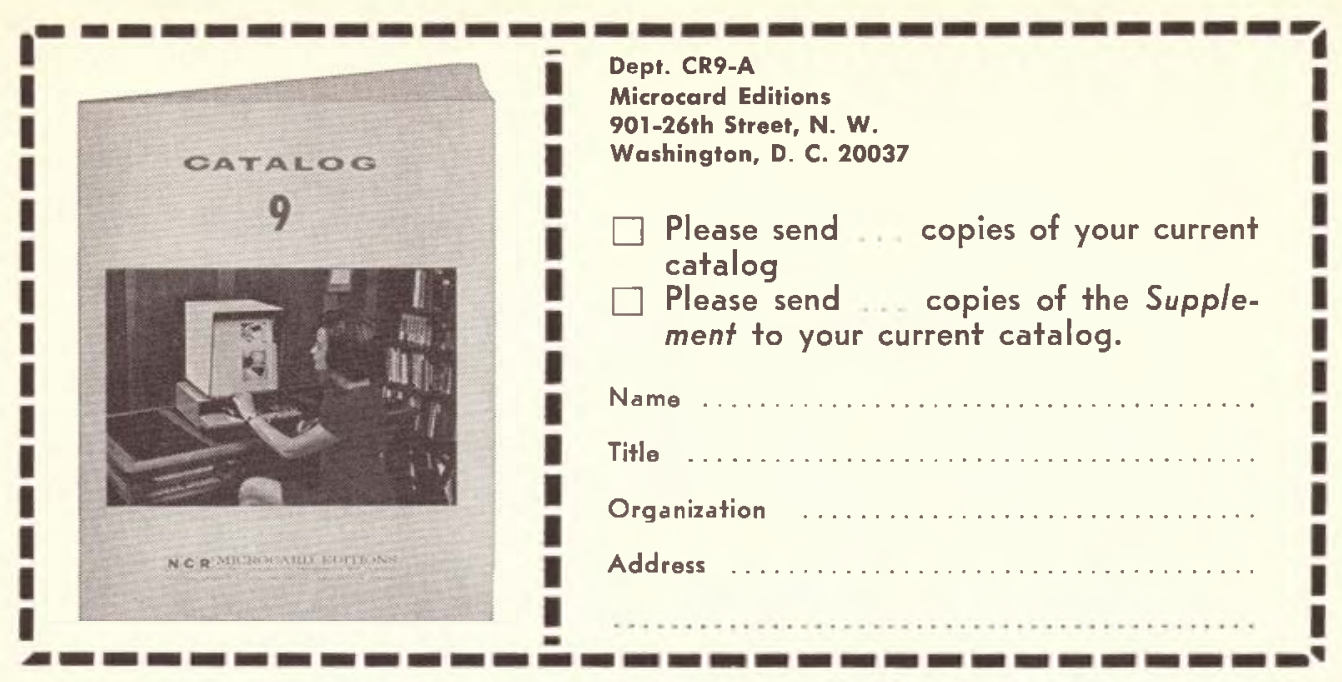

\section{NOW AVAILABLE}

Academia de la Historia, Madrid. MEMORIAL HISTORICO ESPANOOL. COLECCION DE DOCUMENTOS, OPUSCULOS Y ANTIGUEDADES QUE PUBLICA LA REAL ACADEMIA DELA HISTORIA. Madrid, I85I1918. 48 vols.

ARCHIV FÜR ÖSTERREICHISCHE GESCHICHTE. Vienna I848-1944. Vols. I-II6

ARGOSY (England) Vols. 1-75 (1866-1901)

DAEDALUS 1955-66

DICCIONARIO ENCICLOPEDICO HISPANO-AMERICANO. 28 vols. \$ \$199.00

Gt. Brit. Foreign Office. BRITISH AND FOREIGN STATE PAPERS. Vols. I-I38 (1812/14-1939)

$\$ 1,000.00$

UN MONTHLY CHRONICLE $1964-67$

UNITED NATIONS REVIEW. Vols. I-II (1954-64)

U. S. Library of Congress. AUTHOR CATALOG: CUMULATIVE LIST OF WORKS REPRESENTED BY LIBRARY OF CONGRESS PRINTED CARDS, 1948-52. Ann Arbor 1953. 24 vols.

U. S. Library of Congress. MONTHLY CHECKLIST OF STATE PUBLICATIONS. Vols. I-57 (1912-67)

The above titles are all on microfiche and microopaque cards that are $105 \times 148 \mathrm{~mm}\left(4^{\prime \prime} \times 6 "\right)$, unless indicided dothenise 


\section{A lot of colleges are buying library books when they should be buying libraries.}

When you order your books through the Xcrox College Library Program, all you do to set up your library is unpack it.

We can send you the complete 2,000-volume Choice Opening Day Collection*, along with 4,500 enrichment titles (including Choice's Outstanding Academic Books and 500 out-of-print titles from the ALA booklist, Books for College Libraries).

By ordcring your library from us, you save yourself the time and trouble of going through hundreds of catalogs and booklists. And you save your college the expense of haring thousands of orders typed up and mailed out.

Every book is listed in one annotated catalog. All of them-or as few as 100 - can be had with one order. And every book comes fully cataloged and processed to LC standards. If you're about to start a new college library-or add to an existing one-write for the free Xerox Collcge Library Program Catalog.

Then, you'll be able to stop buying your library book by book. And start buying your books by the library.

\section{University Microfilms XEROX}




\section{APPRENTICE SURVEYORS}

Names of 115 librarians who would welcome opportunities to serve as apprentice surveyors have been collected by the ACRL Committee on Library Surveys. These are persons who wrote in response to an invitation from the Committee in the November 1968 issue of CURL News; they are located in 33 states and 2 Canadian provinces, and their interests and special qualifications are as diverse as the problems encountered in surveys of college and university libraries.

Collection of the names was the first step in an effort by the Committee to increase the number of well qualified surveyors by providing opportunities for experience. The Committee recommends that each survey team include an apprentice member, and invites directors of surveys to draw upon its roster. It will welcome opportunities to suggest names of prospective apprentices who seem to be particularly well prepared to contribute to any survey that is being planned. Requests for information should be addressed to Edwin E. Williams, Chairman, ACRL Committee on Library Surveys, Widener Library 183, Harvard University, Cambridge, Mass. 02138.

\section{ACRL/JCLS PRECONFERENCE}

\footnotetext{
"New Strategies for Learning: the Impact of Instructional Technology Upon the Junior College" will be the theme of a preconference sponsored by the American Association of Junior Colleges and the Association of College and Research Libraries at Atlantic City from June 19-21. Planned to stimulate dialogue between administrators, faculty, librarians and media specialists; the two days of sessions will include demonstrations, concurrent workshops, and contact with resource persons. Major presentations will be made by Bill J. Priest, chancellor, Dallas County Junior College District, Dallas, Texas; Gabriel Ofiesh, chairman, department of educational technology, Catholic University, Washington, D.C.; James Zigerall, Dean, TV College, Chicago City College; and Carol Zion, assistant to the vice-president, Miami Dade Junior College.

Maurice B. Mitchell, chancellor of the University of Denver and former president and editorial director of Encyclopaedia Britannica, will speak at the banquet to be held in connection with the preconference on Friday, June 20. Attendance is limited to 500 persons, and the registration fee, including three meals, is $\$ 50$. Reservation forms and information may be requested from the Association of College and Research Libraries, American Library As-
}

sociation, 50 East Huron Street, Chicago, Illinois 60611 .

\section{SUBJECT ANALYSIS OF LIBRARY MATERIALS}

An American Library Association Preconference Institute sponsored by Information Science and Automation Division, Resources and Technical Services Division's Cataloging and Classification Section, and Columbia University, June 19-21, Traymore Hotel, Atlantic City.

A 1969 updating of the Conference on Subject Analysis of Library Materials, Columbia University, 1952, to provide an interpretive overview of the state of the art of subject analysis, especially as it has developed in the last twenty years.

Registration blanks will be mailed to all ALA members. Registrations to the limit of 700 will be accepted with the registration fee of $\$ 35.00$ on a first-come, first-served basis. The fee includes a Banquet ticket, coffee service during the meeting breaks, and one copy of the proceedings to be published by Columbia University, School of Library Service.

\section{INSIDE THE DLP . .

$$
\text { (Continued from page 105) }
$$

\section{Applicants}

Branches may now apply for Supplemental and Special Purpose Types A and B grants, as well as Basic grants, through the parent institution. Beginning in 1969-70, new institutions may apply for Basic grants one year before they open.

These five paragraphs are necessarily brief and sketchy. The new program documents for 1968-69 will provide a comprehensive treatment of the new Title Il-A regulations.

You will note on the last two pages of the Instructions the addresses and phone numbers of our nine Regional Library Service program officers. Call the one in your region if you need further assistance and information about the Title II-A programs.

\section{PERSONNEL . . .}

$$
\text { (Continued from page 132) }
$$

association with the North Texas State University library.

Mrs. Natalie NotKin has retired after twenty years of service with the University of Washington libraries.

Mrs. Marion Stanton has retired after eleven years of service with the University of Washington libraries.

NAOMI StreE', a member of the staff of the New York Public library's art and architecture division for the past eighteen years, retired on December 31, 1968. 